\title{
KERAWANAN BANJIR ROB DAN PERAN GENDER DALAM ADAPTASI DI KECAMATAN PEKALONGAN UTARA
}

\author{
Crestanti Widya Utami ${ }^{1}$ \\ Sri Rum Giyarsih ${ }^{2}$ \\ Muh Aris Marfai ${ }^{3}$ \\ Trida Ridho Fariz ${ }^{4}$ \\ Ilmu Lingkungan, Sekolah Pascasarjana, Universitas Gadjah Mada ${ }^{1}$ \\ Fakultas Geografi, Universitas Gadjah Mada ${ }^{2,3}$ \\ Ilmu Lingkungan, Universitas Negeri Semarang ${ }^{4}$ \\ *Coresponding author. e-mail: crestanti.utami@gmail.com
}

\begin{abstract}
The coastal of Pekalongan City is one of the tidal flood-prone areas, which has been happening for more than 10 years. This condition has a social impact felt by the community, such as a shift in gender roles in carrying out daily activities. This study aims to identify the tidal flood susceptibility area and assess the division of gender roles in society as a form of adaptation. The method used in this research is a mixed-method using quantitative and qualitative. This research begins with making a flood hazard class map using the higher high water level (HHWL) and DEM values. Furthermore, the researcher conducted a descriptive analysis of the social situation understudy and then performed the data triangulation. In collecting the data, the researcher used literature study, interviews, observation, and documentation. The results obtained are that the flood hazard can be determined in each sub-district with low, medium, and high flood classes. The division of reproductive roles is still borne by women and the role of community management is still dominated by men. There is discrimination against women in the high flood area of Panjang Wetan Village, seen in the double burden on women with husbands or men who work as fishermen on large boats or outside the city. This happens because they have to play a productive and reproductive role simultaneously.
\end{abstract}

Keywords: gender roles, women's discrimination, adaptation strategies, tidal flood

\begin{abstract}
ABSTRAK
Pesisir Kota Pekalongan merupakan salah satu wilayah rawan banjir rob, yang mana sudah terjadi lebih dari 10 tahun. Kondisi ini memberikan dampak sosial yang dirasakan oleh masyarakat seperti terjadinya pergeseran peran gender dalam melakukan aktivitas sehari-hari. Penelitian ini bertujuan untuk mengidentifikasi area rawan banjir rob serta mengkaji pembagian peran gender pada masyarakat sebagai bentuk adaptasi. Metode yang digunakan yaitu mix method dengan kuantitatif dan kualitatif. Penelitian diawali dengan pembuatan peta kelas kerawanan banjir dengan menggunakan nilai elevasi muka air tertinggi (HHWL) dan DEM. Selanjutnya dilakukan analisis deskriptif dari situasi sosial yang dikaji yang kemudian dilakukan triangulasi data. Pengumpulan data menggunakan studi pustaka, wawancara, observasi dan dokumentasi. Hasil yang didapat yakni dapat ditentukan kerawanan banjir di masing-masing kelurahan dengan kelas banjir rendah, sedang dan tinggi. Pembagian peran reproduktif masih dibebankan oleh perempuan dan peran pengelolaan masyarakat masih didominasi oleh laki-laki. Terdapat diskriminasi perempuan di area banjir tinggi Kelurahan Panjang Wetan, terlihat pada terjadinya beban ganda pada perempuan dengan suami atau laki-laki yang bekerja sebagai nelayan kapal besar atau di luar kota, sebab harus menjalankan peran produktif dan reproduktif secara bersamaan.
\end{abstract}

Kata Kunci: peran gender, strategi adaptasi, kerawanan banjir, banjir rob 
Jurnal Planologi Vol. 18 No. 1, April 2021

Available: http://jurnal.unissula.ac.id/index.php/psa

\section{PENDAHULUAN}

Perubahan iklim dunia dipahami salah satunya dengan terjadinya kenaikan muka air laut dan telah banyak memberikan dampak negatif bagi kehidupan. Dampak utama yang dirasakan yakni dari aspek ekonomi berupa hilangnya pendapatan masyarakat dari sektor pertanian, perikanan, industri hingga terendamnya permukiman (Hecht, 2016). Wilayah pesisir Kota Pekalongan merupakan salah satu wilayah rawan banjir rob yang mana sudah terjadi lebih dari 10 tahun terakhir (Maharlika et al., 2020). Hal ini memberikan dampak sosial yang dirasakan oleh masyarakat seperti terjadinya pergeseran peran gender dalam melakukan aktivitas sehari-hari. Sektor publik yang awalnya didominasi oleh laki-laki kini banyak tergantikan oleh perempuan. Laki-laki pesisir yang mulanya dominan bekerja pada sektor perikanan kini beralih profesi bahkan menjadi penggangguran karena menurunnya produksi ikan akibat rob. Kondisi ini menyebabkan perempuan untuk ikut serta mengambil kendali dalam sektor publik. Sejalan dengan Nugraheni (2012) dan Pratiwi (2012) bahwa perempuan pesisir juga ikut serta dalam mencari nafkah sebagai tambahan untuk dapat memertahankan kehidupannya. Perempuan persisir banyak bekerja di industri pengolahan ikan seperti pengawetan dan pengemasan ikan untuk diekspor. Pekerjaan yang dilakukan perempuan dapat meningkatkan ekonomi keluarga, namun disisi lain ada perbedaan dalam hal upah kerja yang diterima perempuan lebih kecil dibanding dengan laki-laki.

Terjadinya pergeseran peran gender pada masyarakat pesisir dalam merespon banjir rob memunculkan terjadinya ketidakseimbangan peran antara laki-laki dan perempuan, sehingga menyebabkan ketidakadilan gender. Ketidakadilan gender menyebabkan diskriminasi, sebab tersebut merupakan beban ganda bagi perempuan pesisir. Ketidakadilan gender meliputi marginalisasi, subordinasi, stereotype atau pelabelan negatif dan beban ganda bagi perempuan (Fakih, 2005). Marginalisasi yang dimaksud di sini yaitu pemiskinan ekonomi terhadap perempuan. Perempuan dianggap memiliki derajad lebih rendah dibandingkan dengan laki-laki yang mencari nafkah untuk keluarga. Sehingga perempuan akan mendapatkan upah yang lebih rendah dalam melakukan pekerjaan atau membantu lakilaki mencari nafkah. Subordinasi yang ada seperti contoh adanya anggapan bahwa perempuan tidak perlu memiliki pendidikan yang tinggi sebab hanya akan bekerja di rumah saja. Pelabelan negatif atau stereotype seperti perempuan memiliki fisik yang lemah dibandingkan dengan laki-laki. Perempuan juga memungkinkan memiliki beban ganda dalam alokasi waktu dalam menjalankan peran produksi, reproduksi dan pengelolaan masyarakat serta politik. 
Terjadinya pembagian peran yang tidak seimbang akan berdampak pada aktivitas yang dilakukan dalam merespon terjadinya banjir rob sebagai bentuk adaptasi. Hal ini membuat perlunya kajian tentang peran gender dalam beradaptasi di tiap kelas banjir. Kajian ini masih jarang dilakukan di Kota Pekalongan walaupun kajian tentang bentuk strategi adaptasi sudah sering dilakukan seperti penelitian Adlina et al., (2019), Andrea et al., (2020) dan Hardoyo et al., (2011). KPPPA (2015) juga menyatakan bahwa adaptasi perubahan iklim tidak netral gender karena perempuan dan laki-laki memiliki kapasitas yang berbeda dan berkontribusi terhadap adaptasi secara berbeda. Berdasarkan hal tersebut, penelitian ini memiliki tujuan untuk mengkaji pembagian peran gender masyarakat terdampak banjir rob pada masing-masing kelas kerawanan banjir dalam melakukan aktivitas sehari-hari sebagai bentuk dari adaptasi. Adaptasi dapat memiliki dampak berbeda terhadap perempuan dan laki-laki serta berpotensi untuk meningkatkan atau mengurangi kesenjangan. Peranan gender apabila dikelola dengan baik dapat menjadi strategi adaptasi masyarakat dalam merespon terjadinya banjir rob di Kecamatan Pekalongan Utara, namun jika sebaliknya akan dapat meningkatkan kerentanan atau diskriminasi gender.

\section{METODE PENELITIAN}

Penelitian dilakukan di Kecamatan Pekalongan Utara, Kota Pekalongan tepatnya pada Kelurahan Kandang Panjang, Panjang Baru dan Panjang Wetan (Gambar 1). Ketiga kelurahan tersebut dipilih mengingat kelurahan tersebut merupakan wilayah rawan banjir dan rob serta memiliki kepadatan penduduk tinggi di Kecamatan Pekalongan Utara (Pemerintah Kota Pekalongan, 2011; BPS Kota Pekalongan, 2019). Wilayah tersebut juga memiliki kemiripan karakteristik wilayah yang berbatasan langsung dengan Laut Jawa dan mayoritas masyarakat bekerja di sektor perikanan.
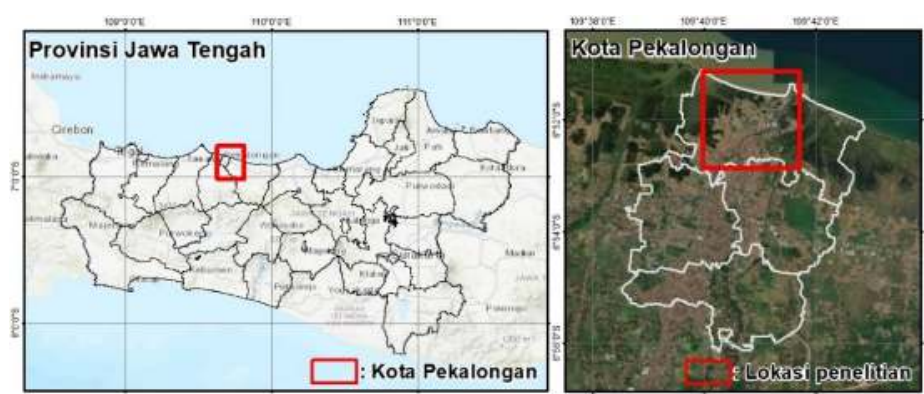

Gambar 1. Lokasi penelitian (Sumber: Hasil analisis, 2020)

Beberapa alat yang digunakan dalam penelitian ini, antara lain berupa perangkat lunak ArcGIS, SAGA 3.0 dan lembar kuesioner. Bahan yang digunakan banyak berupa peta- 
Jurnal Planologi Vol. 18 No. 1, April 2021

Available: http://jurnal.unissula.ac.id/index.php/psa

peta yang berbentuk digital, seperti peta administrasi Kota Pekalongan, peta titik tinggi (height spot) dari BPN Kota Pekalongan, data pasang surut yang diunduh dari inasealevelmonitoring.big.go.id/ipasut/ dan data DEMNAS.

\section{a. Pembuatan peta kerawanan banjir rob}

Kegiatan pembuatan peta genangan banjir rob di Kecamatan Tirto dilakukan dengan menggunakan nilai elevasi muka air tertinggi (HHWL) dan DEM. Nilai HHWL didapat dari perhitungan data pasut Stasiun Pekalongan. Adapun metode perhitungan yang digunakan adalah metode least square dan periode waktu yang digunakan adalah bulan Mei 2018 .

Tahapan selanjutnya adalah pembuatan model genangan banjir dari data DEMNAS dan nilai pasang tertinggi yang secara teknis mirip dengan kajian yang dilakukan Nirwansyah \& Braun (2019) dan Roynaldi \& Maryono (2019). Berdasarkan Julzarika \& Harintaka (2019), DEMNAS pada wilayah Jawa Tengah tidak berbentuk DSM maupun DTM. Sedangkan menurut Mason et al (2016), persyaratan utama dalam pembuatan model genangan banjir rob adalah DEM berbentuk DTM. Oleh karena itu, dalam penelitian ini DEMNAS dikonversi dahulu menjadi DTM menggunakan slope based filtering di SAGA 3.0 seperti yang telah dilakukan oleh Fariz \& Rokhayati (2017). Filter ini diadaptasikan dari pernyataan Vosselman (2000) bahwa perbedaan ketinggian yang besar diantara dua sel yang berdekatan tidak mungkin disebabkan oleh lereng curam di daerah tersebut. Dalam penelitian ini, sel yang diklasifikasikan sebagai tanah (bare earth) adalah sel yang memiliki kelerengan kurang dari 30. Hal ini berdasarkan Marfai et al., (2011) bahwa geomorfologi pantai di Kota Pekalongan relatif landai dengan kemiringan kurang dari 30.

Peta kerawanan banjir rob kemudian dibagi menjadi 3 kelas yaitu rendah, sedang tinggi. Pengkelasan dilakukan dengan equal interval ketinggian genangan banjir. Ketinggian genangan banjir didapat dari selisih antara nilai DTM dengan HHWL. Peta kerawanan banjir rob kemudian diuji akurasi dengan analisis korelasi spearman. Analisis korelasi spearman dilakukan untuk mengetahui derajat hubungan antara ketinggian banjir hasil pemetaan dengan ketinggian banjir di lapangan. Ketinggian genangan banjir rob didapat melalui wawancara. Adapun jumlah sampel yang digunakan untuk uji akurasi adalah sebanyak 30 sampel.

\section{b. Penentuan area kunci}

Area kunci merupakan RW yang digunakan sebagai lokasi penelitian strategi adaptasi gender. Penentuan area kunci dilakukan dengan pemetaan partisipatif mengingat 
peta kerawanan banjir rob hanya bersifat indikatif akibat faktor skala. Tahapan pertama penentuan area kunci adalah melakukan wawancara terhadap perangkat desa apakah peta kerawanan banjir rob yang telah dibuat sudah sesuai dengan kondisi sebenarnya. Tahapan kedua adalah menanyakan RW mana yang memiliki tingkat kerawanan banjir rob sedang dan tinggi. Tahapan ketiga adalah membuat peta batas administrasi RW berdasarkan informasi dari perangkat desa tersebut.

Pemetaan partisipatif merupakan pendekatan yang melibatkan perangkat maupun masyarakat desa dalam proses pemetaan (Fardani, 2019). Partisipasi perangkat desa dalam proses pemetaan banjir rob akan meningkatkan akurasi pemetaan, mengingat mereka sangat paham akan kondisi lingkungan mereka.

\section{c. Pengumpulan dan analisis data peran dan diskriminasi gender}

Teknik pengumpulan data ini menggunakan wawancara, observasi, dokumentasi dan studi pustaka. Penentuan informan pada penelitian ini dilakukan secara purposive sampling yang dipilih dengan pertimbangan informan dianggap berkompeten atau dianggap tahu mengenai informasi yang berhubungan dengan situasi sosial terkait tujuan dari penelitian. Pertimbangan yang digunakan berdasarkan bentuk fisik rumah dengan lantai dan atau atap rumah yang lebih tinggi maupun lebih rendah dari jalan dan diutamakan rumah yang terdapat toko atau warung yang menjadi matapencaharian pemilik rumah. Ini diartikan jika rumah terdampak banjir rob maka sumber pendapatan keluarga juga terdampak banjir rob. Situasi sosial sebagai objek penelitian terdiri dari tiga aspek yakni tempat (place), pelaku (actors) dan aktivitas (activity) (Sugiyono, 2017). Elemen situasi sosial dari penelitian ini: (1) tempat yang menjadi lokasi penelitian yaitu Kelurahan Kandang Panjang, Panjang Baru dan Panjang Wetan Kecamatan Pekalongan Utara; (2) pelaku sebagai informan yaitu masyarakat pesisir baik laki-laki dan perempuan terdampak banjir rob; dan (3) aktivitas yang dikaji meliputi pembagian peran yang terjadi dalam keluarga dan diskriminasi perempuan yang terjadi dalam aktivitas masyarakat. Data yang telah terkumpul dilakukan analisis yang kemudian diuji validitas dan reliabilitas data dengan menggunakan triangulasi data. Triangulasi digunakan untuk menggabungkan data dari berbagai teknik pengumpulan dan sumber data yang ada, sehingga data yang diperoleh akan lebih konsisten, tuntas, dan pasti (Sugiyono, 2017). 
Jurnal Planologi Vol. 18 No. 1, April 2021 Available: http://jurnal.unissula.ac.id/index.php/psa

\section{HASIL DAN PEMBAHASAN}

\section{a. Kerawanan banjir rob}

Banjir rob di Kota Pekalongan merupakan bencana alam yang setiap tahun selalu menggenang terutama pada Kecamatan Pekalongan Utara. Pada bulan Mei tahun 2018 banjir rob juga menggenangi sebagian Kecamatan Pekalongan Barat, sehingga banjir rob yang terjadi pada bulan tersebut dinyatakan sebagai kejadian banjir rob terparah dalam sejarah (Susanto \& Permadi, 2018; Hidayat, 2018). Oleh karena itu penelitian ini menggunakan data pasang surut bulan Mei 2018 untuk perhitungan nilai elevasi muka air tertinggi. Hasil perhitungan menunjukkan bahwa nilai elevasi muka air tertinggi adalah sebesar 2 meter (Gambar 2).

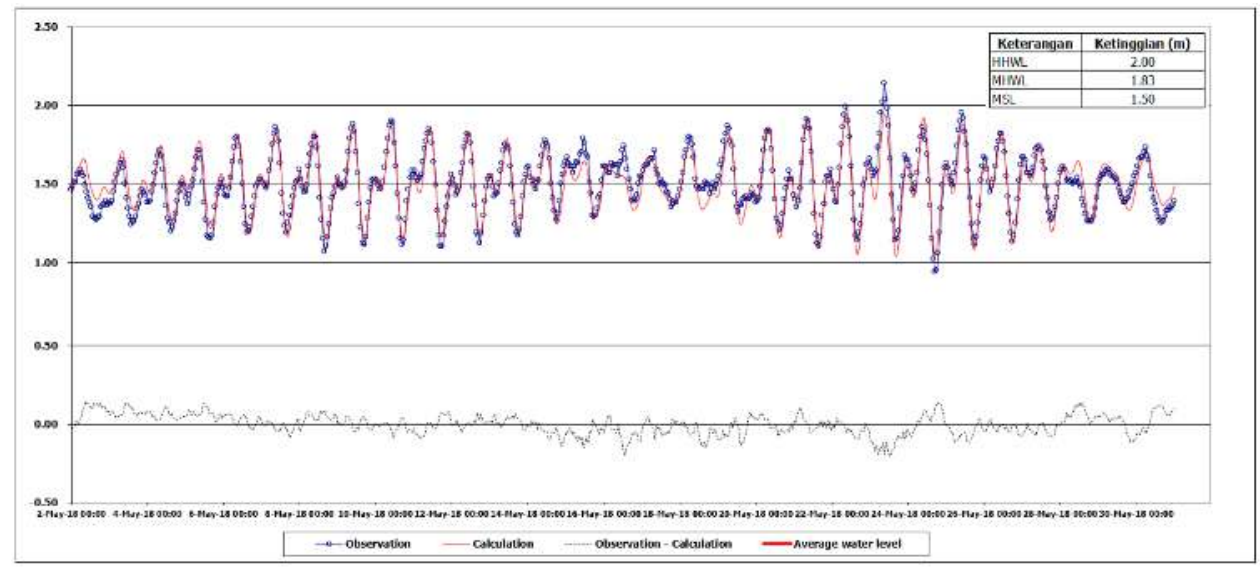

Gambar 2. Hasil perhitungan elevasi muka air menggunakan metode least square (Sumber: Hasil analisis, 2020)

Nilai elevasi muka air tertinggi atau HHWL digunakan sebagai dasar pembuatan peta rawan banjir rob di Kota Pekalongan dengan hasil seluruh wilayah yang menjadi lokasi penelitian tergenang banjir rob. Hasil pemetaan kemudian diklasifikasikan berdasarkan ketinggian genangannya menjadi 3 kelas (rendah, sedang, tinggi). Ketinggian genangan didapatkan dari selisih antara nilai HHWL dengan nilai DTM. Berdasarkan peta kerawanan banjir rob (Gambar 3.), tingkat kerawanan tinggi tersebar di ketiga kelurahan, tetapi Kelurahan Kandang Panjang merupakan kelurahan dengan kelas kerawanan tinggi yang paling luas. Hasil wawancara juga menyebutkan banjir yang terjadi tanggal 23 Mei 2018 menggenangi seluruh wilayah Kelurahan Kandang Panjang. Berbeda dengan Pratama (2019) yang justru Kelurahan Kandang Panjang memiliki ketinggian genangan banjir rob lebih rendah dibandingkan Kelurahan Panjang Wetan dan Kelurahan Panjang Baru. 


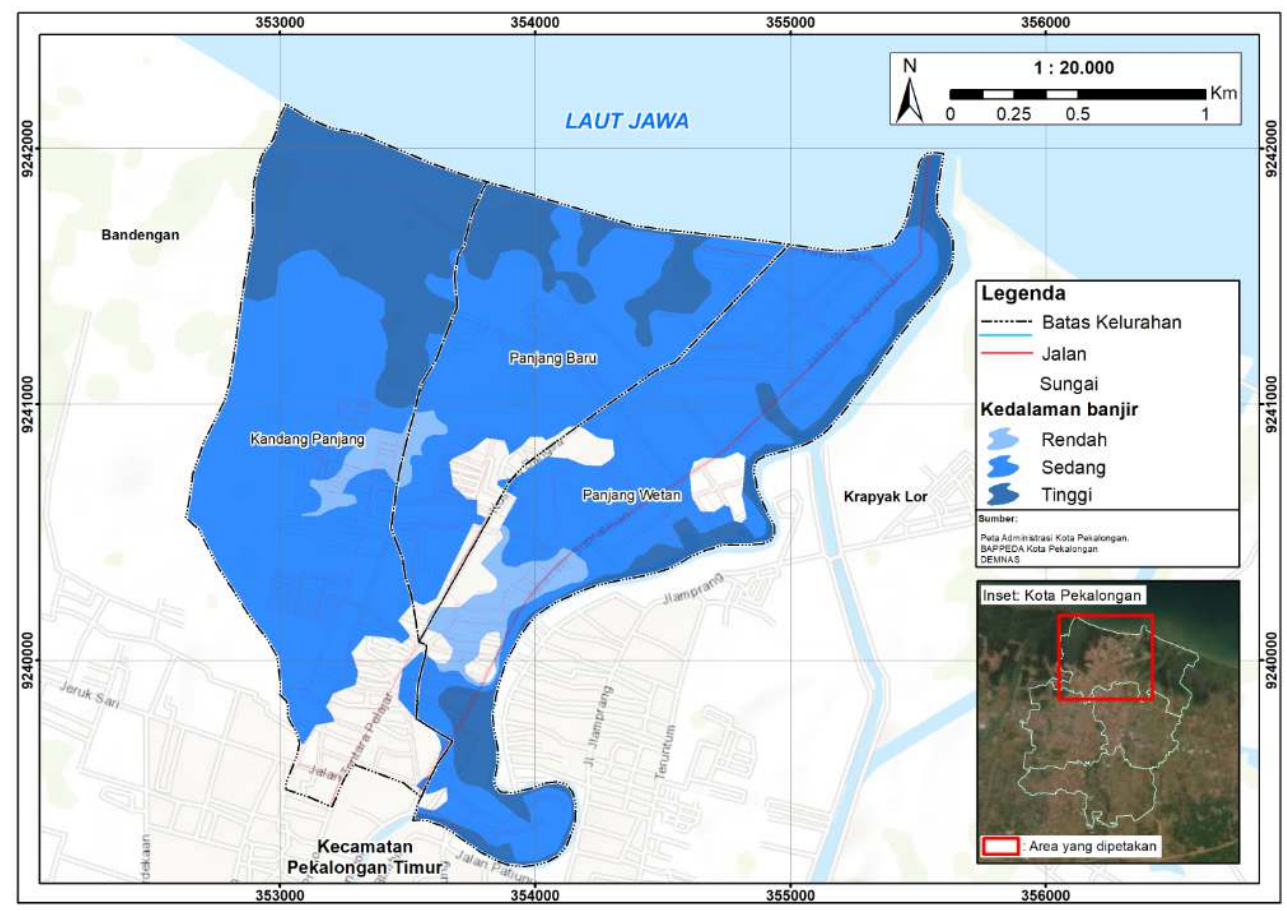

Gambar 3. Peta indikatif kerawanan banjir rob di sebagian Kecamatan Peklongan Utara (Sumber: Hasil analisis, 2020)

Tabel 1. Kelas Kedalaman Banjir

\begin{tabular}{cccc}
\hline Kelas Banjir & $\begin{array}{c}\text { Kedalaman } \\
(\mathbf{c m})\end{array}$ & $\begin{array}{c}\text { Wilayah Kelurahan } \\
\text { sebagai Area Kunci } \\
\text { Penelitian }\end{array}$ \\
\hline $\begin{array}{c}\text { Kelurahan } \\
\text { Kandang } \\
\text { Panjang }\end{array}$ & Rendah & 30 & RW 2 \\
\cline { 2 - 4 } & Sedang & 50 & RW 10 \\
\cline { 2 - 4 } $\begin{array}{c}\text { Kelurahan } \\
\text { Panjang Baru }\end{array}$ & Rendah & 100 & RW 7 \\
\cline { 2 - 4 } & Sedang & 50 & RW 3 \\
\cline { 2 - 4 } $\begin{array}{c}\text { Kelurahan } \\
\text { Panjang Wetan }\end{array}$ & Tinggi & 100 & RW 5 \\
\cline { 2 - 4 } & Rendah & 45 & RW 10 \\
\cline { 2 - 4 } & Sedang & 70 & RW 3 12 \\
\hline
\end{tabular}

(Sumber: Hasil analisis, 2020)

Kedalaman banjir di Kelurahan Panjang Wetan sedikit berbeda dengan lainnya. Salah satu penyebabnya yakni lokasinya yang berbatasan langsung dengan Laut Jawa dan Sungai Loji sehingga mempermudah air untuk mencapai daratan. Wilayah yang terletak di dekat tubuh air seperti sungai dan saluran air akan memiliki genangan yang lebih dalam (Marfai et al., 2013). Penentuan area kunci ini bertujuan untuk mengidentifikasi dan menganalisis pembagian peran gender dan diskriminasi perempuan yang terjadi sebagai respon terhadap banjir rob yang dilakukan masyarakat di tiap kelas banjir. 
Banjir rob terjadi Kelurahan Kandang Panjang di tahun 2018 dengan kedalaman \pm $30 \mathrm{~cm}$ hingga $1 \mathrm{~m}$ dengan area banjir RW 2 termasuk dalam kelas rendah, RW 10 kelas sedang dan sebagian RW 7 merupakan kelas banjir tinggi (Gambar 4.). Saat penelitian ini dilakukan, wilayah Kelurahan Kandang Panjang bagian utara telah dibangun tanggul raksasa sepanjang 7,6 km mulai dari Kelurahan Kandang Panjang ke barat hingga perbatasan Kabupaten Pekalongan. Tanggul yang dibangun oleh Kementerian Pekerjaan Umum dan Perumahan Rakyat (PUPR) ini diresmikan pada Januari 2020. Adanya tanggul ini mengakibatkan pasang air laut tertahan di wilayah ini dan mengalir menuju ke tempat yang lebih rendah yaitu di Kelurahan Panjang Baru dan Panjang Wetan.
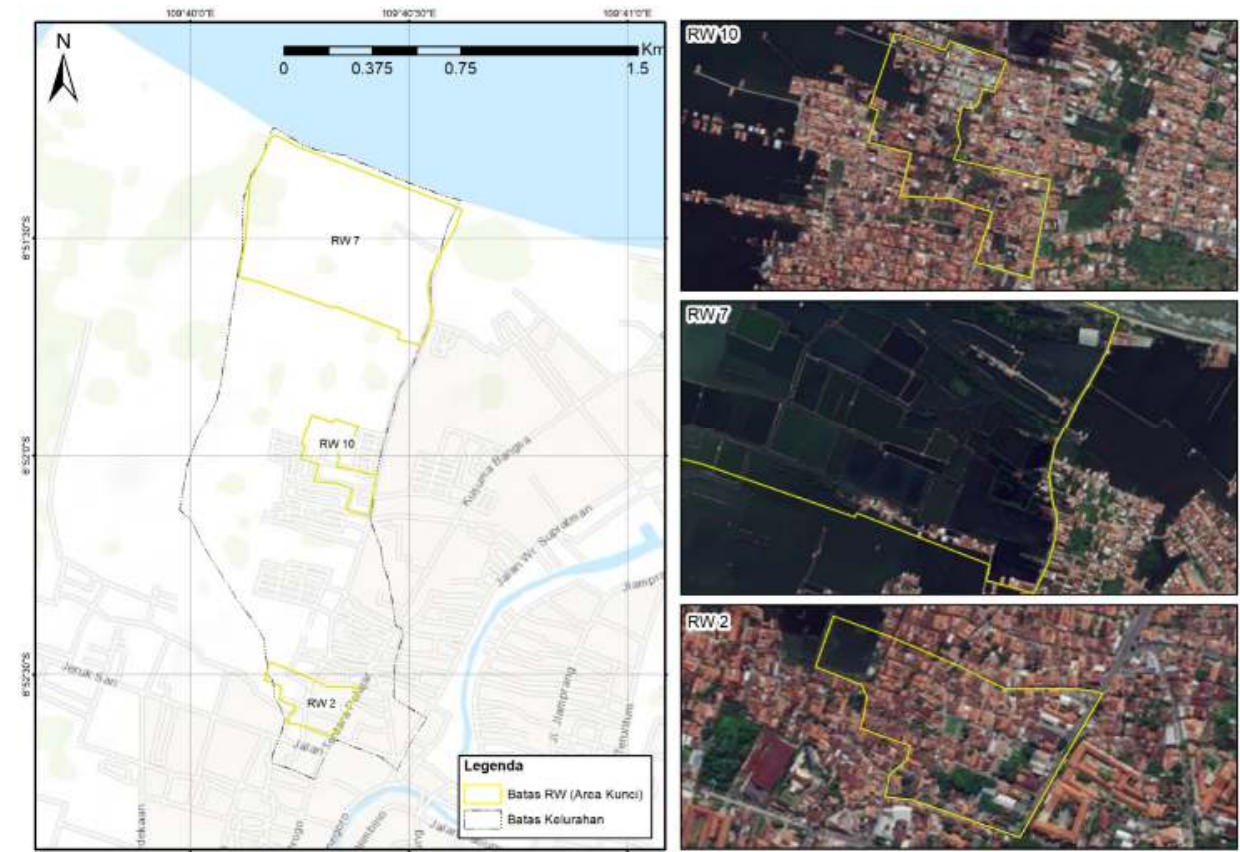

Gambar 4. Area Kunci Kelurahan Kandang Panjang (Sumber: Hasil analisis, 2020)

Kelurahan Panjang Baru merupakan kelurahan yang terletak diantara Kelurahan Kandang Panjang dan Panjang Wetan. Kelurahan ini merupakan pemekaran dari Kelurahan Panjang Wetan sekitar 10 tahun yang lalu. Telah banyak terjadi perubahan lahan dari sawah menjadi lahan terbangun untuk permukiman dan gedung Institut Agama Islam Negeri (IAIN), sehingga semakin berkurang area resapan air yang ada di wilayah tersebut hingga terjadi puncak banjir di tahun 2018. Genangan banjir di Kelurahan Pajang Baru bekisar antara $30 \mathrm{~cm}$ hingga $1 \mathrm{~m}$ dan dikategorikan menjadi banjir rendah dengan wilayah RW 3 , banjir sedang RW 5 dan banjir tinggi RW 10 (Gambar 5.).

Kelurahan Panjang Wetan merupakan kelurahan yang berbatasan langsung dengan Laut Jawa di bagian utara dan Sungai Loji di bagian timur. Lokasinya yang demikian 
menjadi salah satu penyebab pasang air laut mudah untuk mencapai permukiman. Banjir rob yang terjadi tahun 2018 memiliki ketinggian $\pm 45 \mathrm{~cm}$ hingga $1 \mathrm{~m}$ dengan durasi genangan banjir 1-2 hari di kelas banjir rendah. Banjir rob yang terjadi terbagi menjadi 3 kelas yaitu banjir kelas rendah di RW 3, sedang di RW 12 dan tinggi di RW 13 (Gambar 6.).
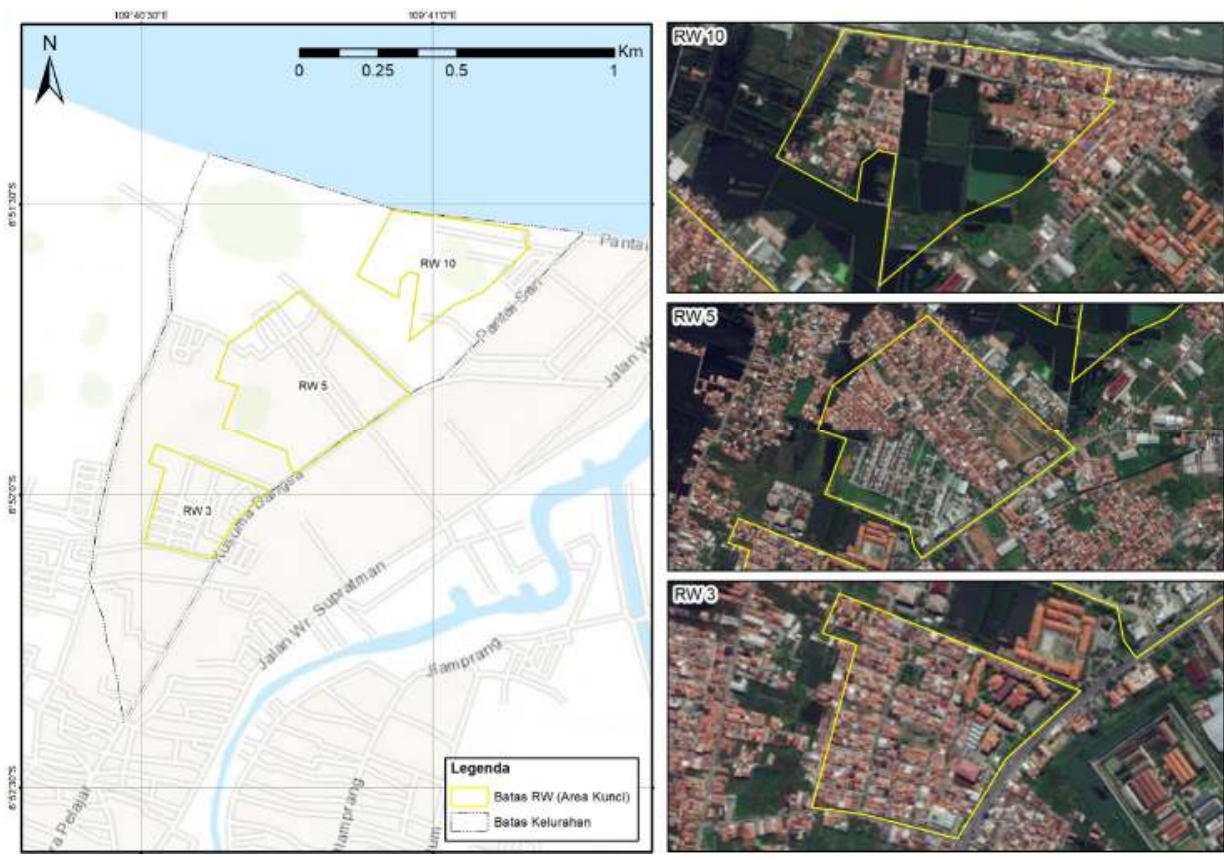

Gambar 5. Area kunci Kelurahan Panjang Baru (Sumber: Hasil Penelitian, 2020)
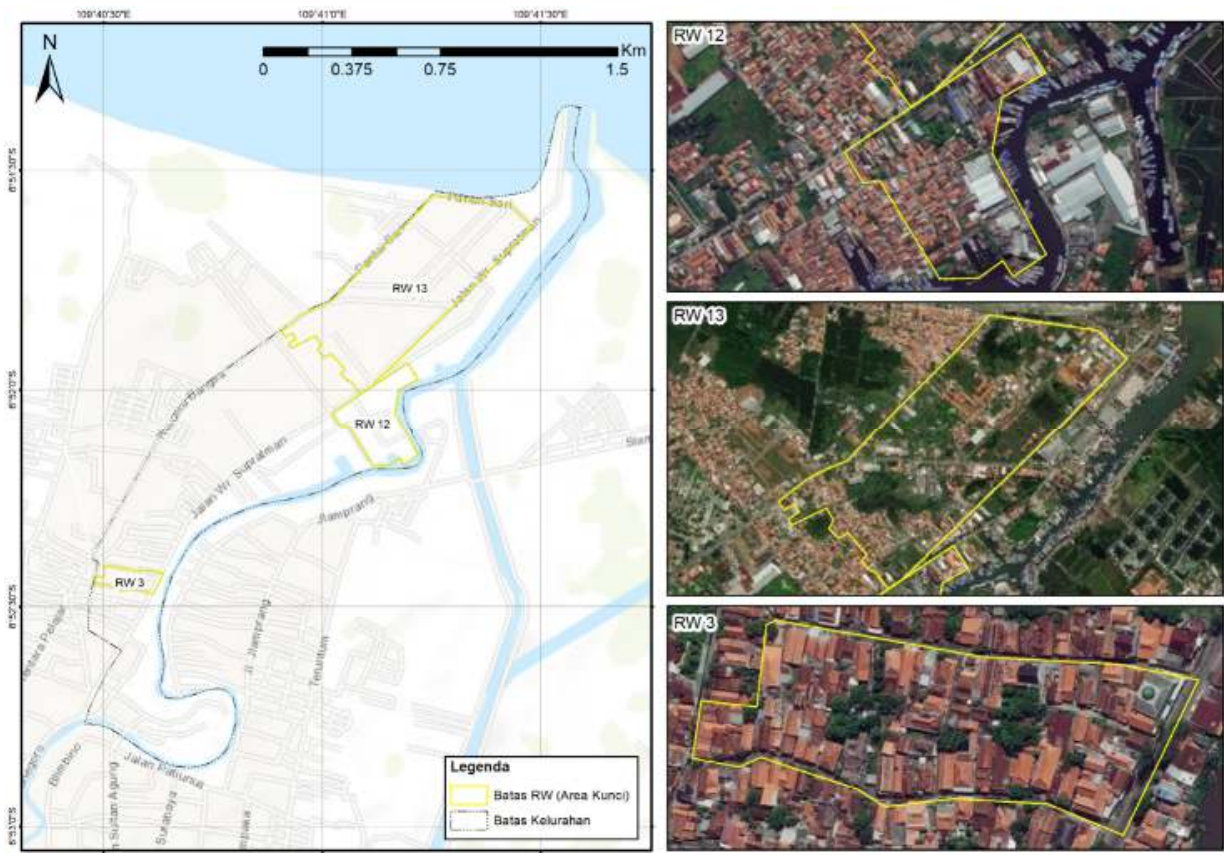

Gambar 6. Area Kunci Kelurahan Panjang Wetan (Sumber: Hasil analisis, 2020) 
Jurnal Planologi Vol. 18 No. 1, April 2021

Available: http://jurnal.unissula.ac.id/index.php/psa

\section{b. Adaptasi masyarakat di tiap kelas banjir rob}

Banjir rob merupakan naiknya permukaan air laut akibat dari pemanasan global (Marfai et al., 2013). Terjadinya banjir rob akan memengaruhi kehidupan masyarakat dan juga lingkungannya (Purifiningtyas \& Wijaya, 2016). Banjir rob yang datang setiap tahun di Kecamatan Pekalongan Utara memberikan banyak dampak terhadap aktivitas masyarakatnya. Tidak hanya mengalami kerugian harta benda saja, namun juga terhalangnya aktivitas sekolah, bekerja dan kegiatan sosial lainnya. Masyarakat dituntut untuk terus melakukan aktivitas terutama bekerja di tengah banjir rob agar kebutuhan sehari-hari dapat terus terpenuhi. Adaptasi sebagai respon yang telah dilakukan masyarakat dalam menghadapi banjir rob cenderung sama pada tiap area kelas banjir, namun adaptasi lebih terlihat pada area banjir kelas tinggi yang berada di wilayah yang memiliki jarak dekat dengan pantai (Tabel 2.)

Tabel 2. Aktivitas Masyarakat dalam Merespon Banjir Rob

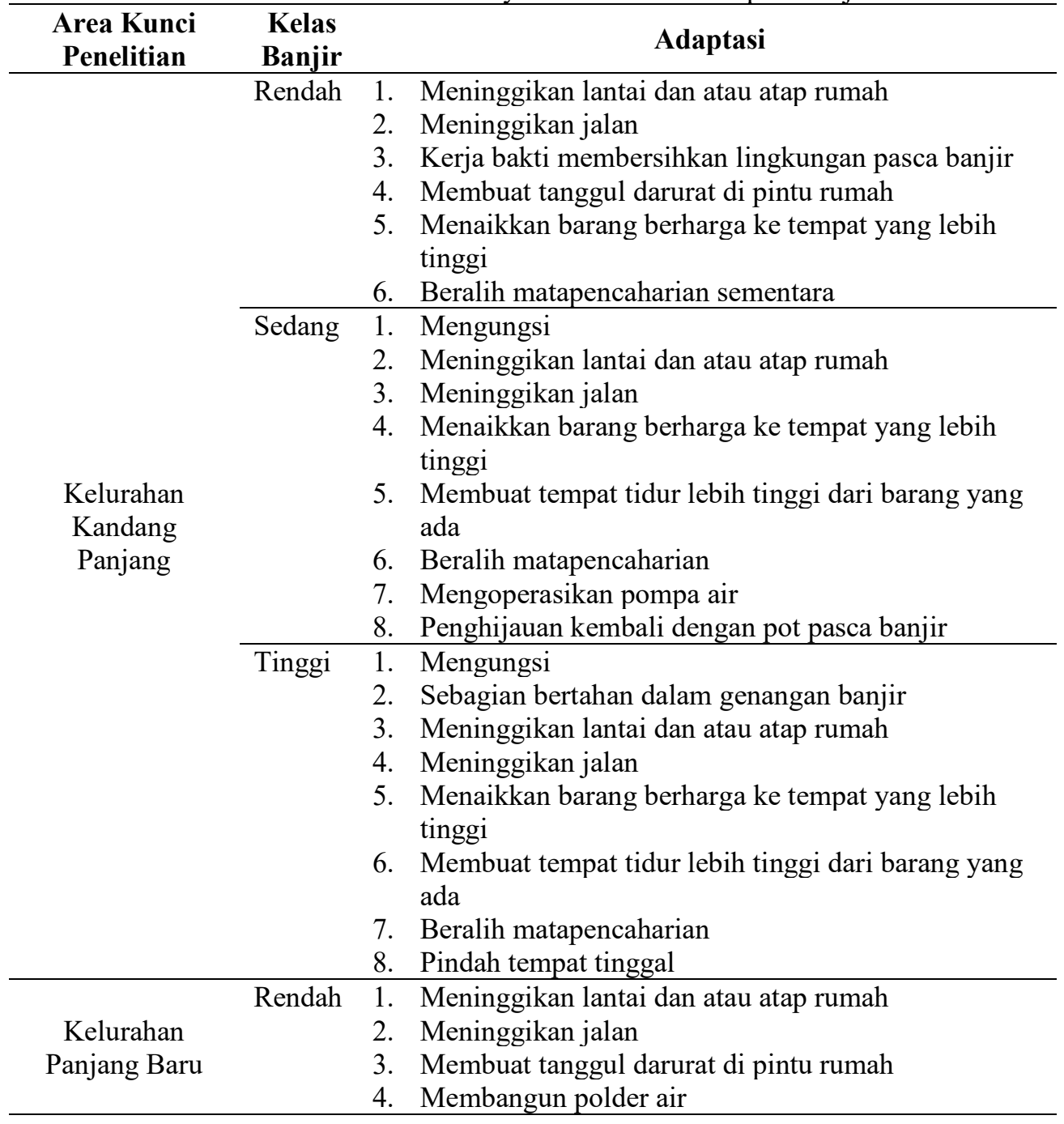

Crestanti Widya Utami, Sri Rum Giyarsih, Muh Aris Marfai, Trida Ridho I103 Kerawanan Banjir Rob dan Peran Gender ... 
Jurnal Planologi Vol. 18 No. 1, April 2021

Available: http://jurnal.unissula.ac.id/index.php/psa

\begin{tabular}{|c|c|c|}
\hline $\begin{array}{l}\text { Area Kunci } \\
\text { Penelitian }\end{array}$ & $\begin{array}{l}\text { Kelas } \\
\text { Banjir }\end{array}$ & Adaptasi \\
\hline & & $\begin{array}{l}\text { 5. Mengoperasikan pompa air } \\
\text { 6. Pindah tempat tinggal }\end{array}$ \\
\hline & Sedang & $\begin{array}{l}\text { 1. Mengungsi } \\
\text { 2. Meninggikan lantai dan atau atap rumah } \\
\text { 3. Meninggikan jalan } \\
\text { 4. Mengoperasikan pompa air } \\
\text { 5. Menaikkan barang berharga ke tempat yang lebih } \\
\text { tinggi } \\
\text { 6. Beralih matapencaharian } \\
\text { 7. Penghijauan kembali dengan pot pasca banjir } \\
\text { 8. Konsumsi air kemasan untuk kebutuhan sehari-hari }\end{array}$ \\
\hline $\begin{array}{c}\text { Kelurahan } \\
\text { Panjang Baru }\end{array}$ & Tinggi & $\begin{array}{l}\text { 1. Mengungsi } \\
\text { 2. Meningikan lantai dan atau atap rumah } \\
\text { 3. Meninggikan jalan } \\
\text { 4. Mengoperasikan pompa air } \\
\text { 5. Menaikkan barang berharga ke tempat yang lebih } \\
\text { tinggi }\end{array}$ \\
\hline \multicolumn{3}{|c|}{ Lanjutan Tabel 2.} \\
\hline $\begin{array}{l}\text { Area Kunci } \\
\text { Penelitian }\end{array}$ & $\begin{array}{c}\text { Kelas } \\
\text { Banjir }\end{array}$ & Adaptasi \\
\hline $\begin{array}{c}\text { Kelurahan } \\
\text { Panjang Baru }\end{array}$ & Tinggi & $\begin{array}{l}\text { 6. Beralih matapencaharian } \\
\text { 7. Konsumsi air kemasan untuk kebutuhan sehari-hari }\end{array}$ \\
\hline \multirow[t]{3}{*}{$\begin{array}{c}\text { Kelurahan } \\
\text { Panjang Wetan }\end{array}$} & Rendah & $\begin{array}{l}\text { 1. Meninggikan lantai rumah } \\
\text { 2. Kerja bakti membersihkan saluran air secara rutin } \\
\text { 3. Penghijauan kembali dengan menanam dalam pot }\end{array}$ \\
\hline & Sedang & $\begin{array}{l}\text { 1. Bertahan dalam genangan banjir } \\
\text { 2. Meninggikan lantai dan atau atap rumah } \\
\text { 3. Meninggikan jalan } \\
\text { 4. Menaikkan barang berharga ke tempat yang lebih } \\
\text { tinggi } \\
\text { 5. Membuat tempat tidur lebih tinggi dari barang yang } \\
\text { ada }\end{array}$ \\
\hline & Tinggi & $\begin{array}{l}\text { 1. Mengungsi } \\
\text { 2. Meninggikan lantai dan atau atap rumah } \\
\text { 3. Meninggikan jalan } \\
\text { 4. Menaikkan barang berharga ke tempat yang lebih } \\
\text { tinggi } \\
\text { 5. Sebagian bertahan dalam genangan banjir } \\
\text { 6. Beralih matapencaharian }\end{array}$ \\
\hline
\end{tabular}

(Sumber: Hasil analisis, 2020)

Masyarakat terdampak banjir rob dengan genangan tinggi cenderung memiliki kemampuan adaptasi yang tinggi dibandingkan dengan yang terdampak banjir rob sedang bahkan rendah (Purifyningtyas \& Wijaya, 2016), terlihat pada penelitiannya yang berada di Kelurahan Bandengan dan Pabean, Kecamatan Pekalongan Utara. Menunjukkan bahwa perbaikan rumah dan infrastruktur banyak dilakukan masyarakat yang berada di genangan banjir rob $30 \mathrm{~cm}$ dibandingkan dengan genangan $<30 \mathrm{~cm}$. Masyarakat yang tinggal dan 
Jurnal Planologi Vol. 18 No. 1, April 2021

berbatasan langsung dengan pantai dianggap memiliki kesadaran yang tinggi mengenai terjadinya erosi pantai dalam hal ini dapat menyebabkan banjir rob dan merupakan masyarakat yang rawan sebab dapat terdampak langsung saat terjadi erosi pantai (Choirunisa \& Giyarsih, 2016). Menurutnya, masyarakat yang tinggal berbatasan langsung dengan pantai akan memiliki pengetahuan yang lebih tinggi mengenai perubahan-perubahan yang terjadi dan cara menghadapi serta penanggulangannya. Area kelas banjir tinggi dalam penelitian ini terutama di Kelurahan Kandang Panjang dan Panjang Baru merupakah wilayah yang berbatasan langsung dengan pantai. Masyarakat yang tinggal berbatasan langsung dengan pantai atau di wilayah pesisir akan memiliki kerawanan tinggi, sebab tidak ada barrier/penghalang air laut untuk langsung menuju ke permukiman (Mussadun et al., 2016). Masyarakat dengan kondisi wilayah tersebut diharuskan untuk lebih mengasah kemampuannya untuk dapat beradaptasi.

\section{c. Peran gender sebagai bentuk adaptasi}

Masyarakat secara umum memandang perbedaan laki-laki dan perempuan sebagai suatu hal yang terjadi secara alamiah sesuai dengan teori nature (Nugraheni, 2012). Pada kenyataannya mengenai teori nurture, interaksi manusia dengan lingkungannya juga akan memengaruhi pengetahuan yang di dapat (Gruber, 2013). Dua teori tersebut saling berhubungan hingga Chomsky (1986) dalam Gruber (2013) mengatakan bahwa orang memiliki hubungan dengan bahasa, sehingga mereka dapat belajar bahasa tertentu, namun kemampuan untuk belajar bahasa tersebut adalah bawaan atau internal dari diri manusia itu sendiri, sehingga demikian juga akan memengaruhi manusia dalam menjalankan perannya. Peran gender yang dikaji dalam penelitian ini yaitu peran produktif, reproduktif dan pengelolaan masyarakat serta politik (Moser, 1993; Karnaen \& Amanah, 2013). Pembagian peran berdasarkan gender apabila dikelola dengan baik dapat menjadi strategi adaptasi masyarakat yang tepat dalam merespon bajir rob yang terjadi, namun jika sebaliknya akan meningkatkan kerentanan dan atau diskriminasi perempuan (Rochmayanto \& Kurniasih, 2013). Peran produktif dalam hal ini yaitu pekerjaan atau matapencaharian yang dikerjakan laki-laki maupun perempuan untuk memperoleh penghasilan. Masyarakat yang menjadi informan di tiap lokasi penelitian baik laki-laki dan perempuan cenderung sama-sama bekerja untuk dapat memperoleh penghasilan (Tabel 3). 
Jurnal Planologi Vol. 18 No. 1, April 2021

Available: http://jurnal.unissula.ac.id/index.php/psa

Tabel 3. Pembagian Peran Produktif Masyarakat

\begin{tabular}{|c|c|c|c|}
\hline \multirow{2}{*}{ Kelurahan } & \multicolumn{3}{|c|}{ Kelas Banjir } \\
\hline & Rendah & Sedang & Tinggi \\
\hline $\begin{array}{l}\text { Kandang } \\
\text { Panjang }\end{array}$ & $\begin{array}{l}\text { - Perempuan : Ibu } \\
\text { Rumah Tangga } \\
\text { - Laki-laki : } \\
\text { bekerja di luar } \\
\text { kota } \\
\text { - Penghasilan tidak } \\
\text { terpengaruh oleh } \\
\text { banjir rob }\end{array}$ & $\begin{array}{l}\text { - Perempuan : } \\
\text { usaha di rumah } \\
\text { - Laki-laki : } \\
\text { nelayan kapal } \\
\text { besar } \\
\text { - Penghasilan } \\
\text { perempuan } \\
\text { terpengaruh } \\
\text { banjir rob } \\
\end{array}$ & $\begin{array}{l}\text { - Perempuan : usaha } \\
\text { di rumah \& Ibu } \\
\text { Rumah Tangga } \\
\text { - Laki-laki : sektor } \\
\text { perikanan dan } \\
\text { perkapalan } \\
\text { - Penghasilan } \\
\text { terpengaruh banjir } \\
\text { rob }\end{array}$ \\
\hline Panjang Baru & $\begin{array}{l}\text { - Perempuan : Ibu } \\
\text { Rumah } \\
\text { Tangga/pekerja } \\
\text { kantoran } \\
\text { - Laki-laki : } \\
\text { pekerja kantoran } \\
\text { - Penghasilan tidak } \\
\text { terpengaruh oleh } \\
\text { banjir rob } \\
\end{array}$ & $\begin{array}{l}\text { - } \text { Perempuan : } \\
\text { usaha di rumah } \\
\text { - Laki-laki : } \\
\text { nelayan kapal } \\
\text { besar \& sektor } \\
\text { perikanan lainnya } \\
\text { - Penghasilan } \\
\text { terpengaruh } \\
\text { banjir rob } \\
\end{array}$ & $\begin{array}{l}\text { - Perempuan : usaha } \\
\text { di rumah } \\
\text { - Laki-laki : nelayan } \\
\text { kapal besar \& sektor } \\
\text { perikanan lainnya } \\
\text { - Penghasilan } \\
\text { terpengaruh banjir } \\
\text { rob }\end{array}$ \\
\hline $\begin{array}{l}\text { Panjang } \\
\text { Wetan }\end{array}$ & $\begin{array}{l}\text { - Perempuan : Ibu } \\
\text { Rumah Tangga } \\
\text { - Laki-laki : buruh } \\
\text { - Penghasilan laki- } \\
\text { laki terpengaruh } \\
\text { oleh banjir rob }\end{array}$ & $\begin{array}{l}\text { - Perempuan : } \\
\text { usaha di rumah } \\
\text { - Laki-laki : buruh } \\
\text { industri kapal } \\
\text { - }\end{array}$ & $\begin{array}{l}\text { - Perempuan : buruh } \\
\text { industri pengolahan } \\
\text { ikan } \\
\text { - Laki-laki : nelayan } \\
\text { kapal besar \& } \\
\text { bekerja di luar kota }\end{array}$ \\
\hline \multicolumn{4}{|c|}{ Lanjutan Tabel 3.} \\
\hline \multirow{3}{*}{ Kelurahan } & \multicolumn{3}{|c|}{ Kelas Banjir } \\
\hline & Rendah & Sedang & $\begin{array}{c}\text { Tinggi } \\
\end{array}$ \\
\hline & & $\begin{array}{l}\text { Penghasilan } \\
\text { terpengaruh } \\
\text { banjir rob }\end{array}$ & $\begin{array}{l}\text { - Penghasilan } \\
\text { perempuan } \\
\text { terpengaruh banjir } \\
\text { rob }\end{array}$ \\
\hline
\end{tabular}

(Sumber: Hasil analisis, 2020)

Hanya sebagian kecil perempuan yang menjadi ibu rumah tangga tanpa penghasilan.

Masyarakat di lokasi penelitian sebagian besar bekerja di sektor perikanan dan perdagangan.

Laki-laki di area banjir sedang dan tinggi cenderung bekerja sebagai nelayan kapal besar dengan masa kerja paling cepat empat bulan, sedangkan perempuan sebagian memiliki usaha seperti warung makanan ringan, laundry dan penjaja makanan keliling. Perempuan memilih untuk bekerja di rumah dengan membuka usaha warung sebab selain dapat menambah penghasilan juga dapat mengerjakan pekerjaan domestik seperti mengurus anak (Karnaen \& Amanah, 2013). Sedangkan untuk area banjir rendah perempuan cenderung menjadi ibu rumah tangga tanpa penghasilan. Saat banjir terjadi aktivitas dalam menjalankan usaha di rumah menjadi tersendat, namun sebagian masyarakat terdampak tetap menjalankan 
aktivitasnya dalam bekerja. Bagi masyarakat yang bekerja sebagai buruh di industri perikanan dan perkapalan, libur atau tidaknya pekerjaan mereka ditentukan oleh pemilik usaha. Seringkali meskipun banjir menggenang tidak ada waktu libur, sebab produksi harus tetap berjalan untuk memenuhi kebutuhan pasar, sehingga masyarakat merasa sedikit terbebani. Di satu sisi tetap harus menjalankan pekerjaannya demi mendapatkan penghasilan namun di sisi lain juga harus menyelamatkan dan menjaga rumah agar tidak semakin terendam banjir. Seperti yang terjadi di Pegunungan Kabupaten Solok, perempuan masih erat dengan kegiatan domestik seperti mencuci, memasak dan melahirkan di sela-sela melakukan kegiatan di ladang, ini menurut Fakih (2005) mengartikan bahwa masyarakat masih kuat menganut nilai-nilai gender. Kebutuhan keluarga baik dari segi ekonomi maupun sosial juga akan menjadi tanggung jawab perempuan dengan suami atau laki-laki yang bekerja di luar kota maupun sebagai nelayan dengan kapal besar (Purwanti, 2013). Hal ini berpengaruh terhadap peran yang dilakukan masing-masing individu dalam kehidupan sehari-hari. Bagi laki-laki dan perempuan dalam satu rumah tangga yang sama-sama bekerja memiliki peran produktif yang sama dalam hal ini adalah bekerja untuk memperoleh pendapatan.

Masyarakat di masing-masing area penelitian masih beranggapan peran reproduktif atau yang berhubungan dengan tanggung jawab pengasuhan anak dan pemenuhan kebutuhan domestik, merupakan tugas perempuan. Sama seperti yang terjadi di pesisir Kabupaten Demak, perempuan juga masih mendominasi dalam melakukan kegiatan domestik atau menjalankan peran reproduktif (Nugraheni, 2012). Kondisi ini ditegaskan oleh Mahanani (2003) dalam Rochmayanto \& Kurniasih (2013) bahwa pembagian kerja laki-laki dan perempuan dipengaruhi oleh nilai dan norma dalam masyarakat, pekerjaan-pekerjaan yang bersifat domestik dan tidak memerlukan tenaga yang kuat serta masih menggunakan teknologi tradisional dikerjakan oleh perempuan, sedangkan laki-laki banyak menghabiskan waktu di sektor publik sehingga kurang berperan dalam hal reproduktif. Ini juga sejalan dengan Karnaen \& Amanah (2013) dalam penelitiannya di Desa Tanjung Pasir Kabupaten Tangerang bahwa adanya hubungan antara pandangan tentang gender dengan pembagian peran dalam rumah tangga perikanan. Pandangan tersebut yakni semakin rendahnya pemahaman mengenai gender akan membuat lebih banyak perempuan dalam melakukan aktivitas reproduktif dan laki-laki tidak akan berperan di dalamnya. Ini akan menjadi tambahan aktivitas jika perempuan juga melakukan perannya dalam hal produktif atau bekerja untuk memperoleh pendapatan. Aktivitas tersebut akan menjadi beban ganda bagi 
Jurnal Planologi Vol. 18 No. 1, April 2021

perempuan jika dilakukan tanpa adanya pembagian tugas khususnya dalam peran reproduktif. Perempuan akan lebih rentan terhadap bencana dan degradasi lingkungan dibanding dengan laki-laki (Rismawati et al., 2018). Kerentanan tersebut tidak hanya dari aspek biologis dan sosial, namun juga mengenai masih rendahnya kesempatan perempuan dalam pengambilan keputusan dan juga aspek ekonomi (Ferris et al., 2013). Selain itu, perempuan merupakan pemegang kendali dalam pengelolaan sumber daya alam yang merupakan hasil dari tanggung jawab dalam pemenuhan kebutuhan domestik (KPPPA, 2015).

Waktu yang digunakan dalam kegiatan produksi atau yang berhubungan dengan pekerjaan untuk memperoleh pendapatan dan reproduksi mengenai pemenuhan kebutuhan domestik dan pengasuhan anak lebih besar dibanding dengan laki-laki, sehingga menjadikan berkurangnya alokasi waktu kegiatan sosial oleh perempuan (Rochmayanto \& Kurniasih, 2013). Ini terkait dengan peran pengelolaan masyarakat yang dilakukan. Laki-laki dan perempuan sama-sama menjalankan kegiatan sosial masyarakat seperti PKK dan rapat RT maupun RW, namun tidak demikian dengan masyarakat di area banjir tinggi Kelurahan Panjang Wetan. Di wilayah tersebut sebagian besar perempuan bekerja di industri pengolahan ikan dan laki-laki sebagai nelayan kapal besar ataupun bekerja di luar kota, sehingga tidak memiliki waktu untuk mengikuti kegiatan sosial tersebut. Untuk peran pengelolaan politik cenderung dilakukan oleh laki-laki, seperti pada Komunitas Tanggap Bencana Kelurahan Kandang Panjang dan Komunitas Jogo Samudro Kelurahan Panjang Baru. Kepemimpinan ketua RW dari sembilan area penelitian juga diduduki oleh laki-laki. Hanya kepemimpinan lurah Kelurahan Panjang Baru saja yang dijalankan oleh perempuan. Sesuai dengan yang disebutkan Nugraheni (2012), Ferris et al. (2013) dan Rismawati et al. (2018) bahwa perempuan masih tertinggal dalam proses pengambilan kebijakan dan keputusan politik dalam mengakses sumber kehidupan. Dominasi ini dapat memunculkan terjadinya ketidakseimbangan gender, sedangkan mengenai perbedaan upah kerja yang diterima perempuan dan laki-laki dalam industri pengolahan ikan disebabkan oleh perbedaan jenis pekerjaan dan waktu bekerja yang berbeda. Perempuan dianggap memiliki tenaga yang tidak lebih kuat dengan laki-laki (Rochmayanto \& Kurniasih, 2013), sehingga pekerjaan yang dilakukan perempuan dianggap lebih ringan dengan waktu kerja yang lebih sedikit pula, sehingga mengharuskan perempuan mendapatkan upah yang lebih rendah dari lakilaki. Adanya anggapan pekerjaan domestik yang selalu dikerjakan perempuan menyebabkan waktu kerja perempuan di industri tersebut lebih sedikit dibandingkan dengan laki-laki. 
Jurnal Planologi Vol. 18 No. 1, April 2021

Available: http://jurnal.unissula.ac.id/index.php/psa

Kondisi demikian dianggap sesuai dengan teori equilibrium yang menganggap laki-laki dan perempuan harus bekerjasama dan bermitra dalam kehidupan keluarga, masyarakat, bangsa dan negara (Nugraheni, 2012).

Menurut Purwanti (2013) pendidikan bagi perempuan di Kecamatan Pekalongan Utara dianggap tidak begitu penting terhadap kemampuan perempuan sehingga menyebabkan ekonomi keluarga hanya menjadi tanggung jawab laki-laki. Berbeda dengan kondisi di lapangan, melalui wawancara diketahui laki-laki dan perempuan seluruhnya menganggap pendidikan sangat penting baik untuk laki-laki maupun perempuan, terlebih untuk tetap dapat memertahankan kehidupan saat terjadi banjir rob. Pendidikan dan pengetahuan sangat penting bagi masyarakat baik laki-laki maupun perempuan untuk dapat lebih mengembangkan kemampuannya dalam melakukan adaptasi banjir rob. Sejalan dengan Choirunisa \& Giyarsih (2016) yag menyebutkan bahwa masyarakat yang memiliki pendidikan tinggi akan lebih mudah dalam memperoleh dan menyerap informasi sehingga dapat menentukan tindakan yang bertujuan mengurangi dampak dari bencana yang akan terjadi. Pengetahuan dan keterampilan perlu didapatkan terlebih oleh perempuan sesuai dengan kondisi wilayah masing-masing agar dapat menunjang kehidupannya pada saat terjadi dan pasca banjir. Selain itu, peningkatan pendidikan dan pengetahuan perempuan juga dibutuhkan guna mengurangi terjadinya stereotype dan subordinasi yang terjadi di masyarakat (Rochmayanto \& Kurniasih, 2013). Kegiatan pemberdayaan perempuan untuk meningkatkan ekonomi telah dilakukan di Keluaran Kandang Panjang dan Panjang Baru. Kegiatan tersebut berupa pengolahan hasil mangrove menjadi sabun, tepung, sirup dan pewarna alami oleh PKK pada area banjir tinggi Kelurahan Kandang Panjang yang berbatasan langsung dengan kawasan mangrove dan Kelompok Wanita Tani di area banjir sedang Kelurahan Panjang Baru. Ini diperlukan sebagai upaya peningkatan kapasitas adaptif dan menurunkan kerentanan perempuan terhadap perubahan iklim (Rochmayanto \& Kurniasih, 2013) yang dalam hal ini banjir rob sebagai salah satu akibatnya.

Penelitian ini masih memiliki beberapa kelemahan yaitu terletak pada tidak dilakukannya analisis keberlanjutan matapencaharian masyarakat pesisir. Matapencaharian masyarakat pesisir rentan terhadap kerusakan sumber daya, sehingga perlu dilakukan analisis dengan menggunakan Coastal Livelihood System Analysys (CLSA) yang merupakan konsep yang digunakan untuk mengidentifikasi matapencaharian aternatif berkelanjutan bagi masyarakat pesisir (Pratiwi, 2012). CLSA dilakukan berdasarkan lima pilar yakni modal manusia, modal sosial, modal fisik, modal alam dan keuangan modal (Chambers, 
Jurnal Planologi Vol. 18 No. 1, April 2021

Available: http://jurnal.unissula.ac.id/index.php/psa

1994; Paulangan et al., 2018). Sedangkan mengenai penentuan rumusan strategi yang akan diusulkan sebagai strategi adaptasi masyarakat di masa mendatang pada penelitian ini tidak secara langsung melibatkan pihak terkait. Sehingga penentuan usulan strategi adaptasi sebaiknya menggunakan diskusi kelompok terarah atau Focus Group Discussion (FGD). Melalui FGD akan lebih terarah dalam menentukan strategi adaptasi yang sesuai dengan kebutuhan masyarakat berdasarkan gender. Diskusi kelompok terarah dan CLSA digunakan oleh Paulangan et al. (2018) dalam mengidentifikasi matapencaharian alternatif yang berkelanjutan. Diskusi kelompok terarah juga digunakan oleh Rakib et al. (2017) dan Naz et al. (2018) untuk menganalisis peran gender dalam beradaptasi menghadapi banjir. Analisis mengenai peran gender dan keberlanjutan matapencaharian masyarakat pesisir sebagai bentuk adaptasi terhadap banjir rob perlu dilakukan mengingat kondisi pesisir yang semakin tidak menentu. Kondisi ini menjadi ancaman tersendiri bagi masyarakat pesisir.

\section{KESIMPULAN DAN SARAN}

Kerawanan banjir pada lokasi penelitian dapat dikategorikan menjadi banjir rendah, sedang dan tinggi di masing-masing kelurahan. Diskriminasi terlihat di area banjir tinggi Kelurahan Panjang Wetan, terlihat pada terjadinya beban ganda pada perempuan dengan suami atau laki-laki yang bekerja sebagai nelayan kapal besar atau di luar kota, sebab harus menjalankan peran produktif dan reproduktif secara bersamaan. Peran reproduktif di masing-masing wilayah masih di dominasi oleh perempuan, sedangkan peran pengelolaan politik didominasi oleh laki-laki. Pemberdayaan perempuan telah dilakukan di area banjir tinggi Kelurahan Kandang Panjang dan area banjir sedang Kelurahan Panjang Baru dengan kegiatan yang dilakukan oleh perempuan untuk meningkatkan ekonomi keluarga.

Penelitian ini masih terdapat kelemahan yaitu terletak pada tidak dilakukannya analisis keberlanjutan matapencaharian masyarakat pesisir dan perumusan strategi adaptasi tidak melibatkan pihak terkait. Oleh karena itu penelitian perlu dilakukan pengembangan dengan menggunakan CLSA. Selain itu penentuan rumusan strategi adaptasi sebaiknya menggunakan diskusi terarah atau FGD.

\section{DAFTAR PUSTAKA}

Adlina, Z. I., Sardjono, A. B., \& Sari, S. R. (2019). ADAPTASI PERMUKIMAN TERDAMPAK BENCANA ROB (Studi Kasus: Kelurahan Bandengan, Kecamatan Pekalongan Utara, Kota Pekalongan). Jurnal Arsitektur ARCADE, 3(1), 21-26. 
Jurnal Planologi Vol. 18 No. 1, April 2021

Available: http://jurnal.unissula.ac.id/index.php/psa

Andrea, R. M., Sudharto, P. H., \& Kismartini, K. (2020, November). Strategi Adaptasi Nonstruktural dalam Menghadapi Banjir Pasang: Studi Kasus Kota Pekalongan. In Seminar Nasional Lahan Suboptimal (No. 1).

Badan Pusat Statistik Kota Pekalongan. (2019). Kecamatan Pekalongan Utara Dalam Angka. BPS Kota Pekalongan: Kota Pekalongan

Chambers, R. (1994). Participatory rural appraisal (PRA): Challenges, potentials and paradigm. World development, 22(10), 1437-1454.

Choirunisa, A. K., \& Giyarsih, S. R. (2016). Kajian Kerentanan Fisik, Sosial, dan Ekonomi Pesisir Samas Kabupaten Bantul Terhadap Erosi Pantai. Jurnal Bumi Indonesia, 5(4).

Fardani, I. (2019, February). Participatory Mapping Solution for Village Potential and Boundary. In The 9th International Conference Rural Research \& Planning Group (pp. 194-208).

Fariz, T. R., \& Rokhayati N. (2017). Konversi DSM Menjadi DTM Menggunakan Filter Berbasis Kelerengan Untuk Pemetaan Banjir Rob di Kecamatan Tirto. Prosiding Seminar Nasional Ke-3 Pengelolaan Pesisir Dan Daerah Aliran Sungai 2017.

Fakih, M. (2005). Analisis Gender dan Transformasi Sosial. Insist Press.

Ferris, E., Petz, D., \& Stark, C. (2013). The year of recurring disasters: A review of natural disasters in 2012. Brookings Institution.

Gruber, T. R. (2013). Nature, nurture, and knowledge acquisition. International journal of human-computer studies, 71(2), 191-194.

Hardoyo, S. R., Marfai, M. A., Ni'mah, N. M., Mukti, R. Y., Zahro, Q., \& Halim, A. (2011). Strategi Adaptasi Masyarakat dalam Menghadapi Bencana Banjir Pasang Air Laut di Kota Pekalongan. Magister Perencanaan Dan Pengelolaan Pesisir Dan Daerah Aliran Sungai (MPPDAS). Program S-2 Geografi, Fakultas Geografi Universitas Gadjah Mada. Yogyakarta. Cetakan Pertama.

Hecht, J. E. (2016). Indonesia: Costs of Climate Change 2050. United States Agency for International Development.

Hidayat, W. (2018). Rob Kota Pekalongan Paling Parah Sepanjang Sejarah. Diakses dari $<$ radarpekalongan.co.id/31845/rob-kota-pekalongan-paling-parah-sepanjangsejarah/> pada 10 Oktober 2020.

Julzarika, A. (2019, August). Indonesian DEMNAS: DSM or DTM?. In 2019 IEEE AsiaPacific Conference on Geoscience, Electronics and Remote Sensing Technology (AGERS) (pp. 31-36). IEEE.

Karnaen, S. M. N., Amanah, S., \& Maulina, S. (2013). Peranan Gender dalam Rumah Tangga Perikanan di Desa Tanjung Pasir, Kecamatan Teluknaga, Kabupaten Tangerang. Sodality: Jurnal Sosiologi Pedesaan [internet].[Diunduh pada 30 Maret 2017], 1(02), 152-164.

Kementerian Pemberdayaan Perempuan dan Perlindungan Anak Republik Indonesia. (2015). Pedoman Umum Adaptasi Perubahan Iklim yang Responsif gender. Jakarta: Kementerian Pemberdayaan Perempuan dan Perlindungan Anak Republik Indonesia.

Marfai, M. A., Pratomoatmojo, N. A., Hidayatullah, T., Nirwansyah, A. W., \& Gomareuzzaman, M. (2011). Model Kerentanan Wilayah Pesisir Berdasarkan Perubahan Garis Pantai dan Banjir Pasang (Studi Kasus: Wilayah Pesisir Pekalongan). RedCarpet Studio. Yogyakarta.

Marfai, M. A., Mardiatno, D., Cahyadi, A., Nucifera, F., \& Prihatno, H. (2013). Pemodelan Spasial Bahaya Banjir Rob Berdasarkan Skenario Perubahan Iklim dan Dampaknya di Pesisir Pekalongan. Jurnal Bumi Lestari Vol. 13 No. 2: 244-256. 
Jurnal Planologi Vol. 18 No. 1, April 2021

Available: http://jurnal.unissula.ac.id/index.php/psa

Ramadhani Maharlika, A., Prawata Hadi, S., \& Lenty Hoya, A. (2020, August). Tidal flooding and coastal adaptation responses in Pekalongan City. In E3S Web of Conferences (Vol. 202, p. 06027).

Mason, D. C., Trigg, M., Garcia-Pintado, J., Cloke, H. L., Neal, J. C., \& Bates, P. D. (2016). Improving the TanDEM-X Digital Elevation Model for flood modelling using flood extents from Synthetic Aperture Radar images. Remote Sensing of Environment, 173, $15-28$.

Mussadun, M., Jannata, P. F., \& Islamiyah, F. W. P. (2016). Upaya Adaptasi Masyarakat Berpenghasilan Rendah (MBR) dalam Menghadapi Bencana Banjir Rob (Studi Kasus: Kampung Tambak Lorok, Kota Semarang). Ruang, 2(4), 331-340.

Naz, F., Doneys, P., \& Saqib, S. E. (2018). Adaptation strategies to floods: A gender-based analysis of the farming-dependent char community in the Padma floodplain, Bangladesh. International Journal of Disaster Risk Reduction, 28, 519-530.

Nirwansyah, A. W., \& Braun, B. (2019). Mapping impact of tidal flooding on solar salt farming in Northern Java using a hydrodynamic model. ISPRS International Journal of Geo-Information, 8(10), 451.

Nugraheni, W., Marhaeni, T., \& Sucihatiningsih, D. W. P. (2012). Peran dan potensi wanita dalam pemenuhan kebutuhan ekonomi keluarga nelayan. Journal of Educational Social Studies, 1(2).

Paulangan, Y. P., Amin, M. A. A., Wahyudin, Y., \& Kodiran, T. (2018). Identifikasi Mata Pencaharian Alternatif Masyarakat Lokal di Calon Kawasan Konservasi Teluk Depapre, Jayapura. Jumabis: Jurnal Manajemen dan Bisnis, 2(2).

Pemerintah Kota Pekalongan. (2011). Peraturan Daerah Kota Pekalongan Nomor 30 Tahun 2011 tentang Rencana Tata Ruang Wilayah Kota Pekalongan Tahun 2009 - 2029. Pemkot Pekalongan: Kota Pekalongan.

Pratama, M. B. (2019, November). Tidal Flood in Pekalongan: Utilizing and Operating Open Resources for Modelling. In IOP Conference Series: Materials Science and Engineering (Vol. 676, No. 1, p. 012029). IOP Publishing.

Pratiwi, M. R. (2012). Dampak Dinamika Banjir Pasang (Rob) terhadap Sistem Sosial Ekologis Kota Semarang (Studi kasus di Kelurahan Tanjung Mas) (Doctoral dissertation, Thesis IPB Bogor).

Purifyningtyas, H. Q., \& Wijaya, H. B. (2016). Kajian Kapasitas Adaptasi Masyarakat Pesisir Pekalongan terhadap Kerentanan Banjir Rob (Doctoral dissertation, UNIVERSITAS DIPONEGORO).

Purwanti, I. F. (2013). Peran Istri Nelayan Kecil dalam Menghadapi Perubahan Iklim (Studi Empiris di Kota Pekalongan) (Doctoral dissertation, Fakultas Ekonomika dan Bisnis).

Rakib, M. A., Islam, S., Nikolaos, I., Bodrud-Doza, M., \& Bhuiyan, M. A. (2017). Flood vulnerability, local perception and gender role judgment using multivariate analysis: A problem-based "participatory action to Future Skill Management" to cope with flood impacts. Weather and climate extremes, 18, 29-43.

Rismawati, S. D., Thoha, I. B., \& Sasongko, S. A. (2018). Geliat Ecofeminisme Pedesaan Dalam Pelestarian Lingkungan (Studi Kasus Di Desa Curug Muncar Pekalongan). Palastren Jurnal Studi Gender, 10(1), 23-46.

Rochmayanto, Y., \& Kurniasih, P. (2013). Peranan Gender dalam Adaptasi Perubahan Iklim pada Ekosistem Pegunungan di Kabupaten Solok, Sumatera Barat. Jurnal analisis kebijakan kehutanan, 10(3), 203-213.

Roynaldi, A. D., \& Maryono, M. (2019). Estimation of Waste Generation from Tidal Flood in North Semarang Sub-District. In E3S Web of Conferences (Vol. 125, p. 07019). EDP Sciences. 
Jurnal Planologi Vol. 18 No. 1, April 2021 Available: http://jurnal.unissula.ac.id/index.php/psa

Sugiyono. (2017). Metode Penelitian Kuantitatif Kualitatif dan $R \& D$. Bandung: Penerbit Alfabeta.

Susanto, B., \& Permadi, G. (2018). 1.363,13 Hektar Wilayah Kota Pekalongan Terendam Air Rob. Diakses dari <jateng.tribunnews.com/2018/05/28/136313-hektar-wilayahkota-pekalongan-terendam-air-rob $>$ pada 10 Oktober 2020.

Vosselman, G. (2000). Slope based filtering of laser altimetry data. International Archives of Photogrammetry and Remote Sensing, 33(B3/2; PART 3), 935-942. 